\title{
CONSPIRACY THEORY AND THE CRITICAL ENTERPRISE
}

\author{
Kevin McKenzie
}

\begin{abstract}
This paper explores the argumentative work undertaken in talk and text about conspiracy theory (CT), relating this to recent scholarly debate regarding the significance of critical inquiry in the context of developments in poststructuralist and postmodern social theory. We examine discussion of CT as a site where the transformation between deconstructive, depth analytic critique and its opposite, realist claims takes place. Meta-theoretical formulations attempting to accommodate both such argumentative gestures in a coherent program for the pursuit of dialogue are shown to be inconsistent with the nature of argumentation as an undertaking to resolve ambiguity in accounts. the sharing of concerns on which agreement is to be founded are the outcome, rather than the basis, of dialogue, even if such an encounter is pursued on the grounds of shared presupposition distinct from the shared concerns which emerge from dialogue. Discussion concerning CT is a site where the formulation of motivation is made to bear on the question of an argument's validity in virtue of either depth analytic or realist assumptions.
\end{abstract}

Keywords: Conspiracy theory, Critical inquiry, Argument, Dialogue, Conversation.

\section{Introduction}

In a recent special issue of Critical Inquiry dedicated to exploring the implications of the current state of critical theory and social critique, Bruno Latour introduces the journal issue with an essay addressed to how fact and fetish are related to one another in a mutually exclusive and yet mutually elaborative relationship that characterizes the logic of modernity (Latour 2004a). Highlighting some of the main points developed elsewhere in his earlier work $(1981,1993,1999)$, Latour seeks to address the question of what has become of critical inquiry in the wake of poststructuralist and postmodern trends in the social sciences. His way into this is to relate the critical enterprise with the project of modernity, making the point that modernity, while an intrinsically critical endeavor, is nevertheless one that sustains a constitutive tension between realist reification on the one hand, and constructivist anti-fetishism on the other. The characteristic operation of the modern constitution is one that involves the variable and selective making relevant of otherwise antithetical moments in argumentative modes of understanding. This tension resides between revelatory, depth analysis, where efforts are made to uncover underlying meaning; and the determination of fact, where some autonomous state-of-affairs is established along the lines of a realist model of discursive/linguistic representationalism. For Latour, part of what characterizes modernity is the work to keep these two moments distinct, such that the mutually 
occasioning relationship between them remains obscure and unarticulated. The result of this obscured dualism is a mode of argumentation in which "You are always right!" (2004: 239):

\begin{abstract}
When naïve believers are clinging forcefully to their objects, claiming that they are made to do things because of the gods, their poetry, their cherished objects, you can turn all of those attachments into so many fetishes and humiliate all the believers by showing that it is nothing but their own projection, that you, yes you alone, can see. But as soon as naïve believers are thus inflated by some belief in their own importance, in their own projective capacity, you strike them by a second uppercut and humiliate them again, this time by showing that, whatever they think, their behavior is entirely determined by the action of powerful causalities coming from objective reality they don't see, but you, yes you, the never sleeping critic, alone can see. Isn't this fabulous? Isn't it worth going to graduate school to study critique? "Enter here, you poor folks. After arduous years of reading turgid prose, you will be always right, you will never be taken in any more; no one, no matter how powerful, will be able to accuse you of naïveté, that supreme sin, any longer? Better equipped than Zeus himself you rule alone, striking from above with the salvo of antifetishism in one hand and the solid causality of objectivity in the other."
\end{abstract}

Latour illustrates these two argumentative moments with examples taken from contemporary debate on a number of different issues. For instance, he discusses the appropriation of critical deconstruction in the political rhetoric relating to environmental degradation, describing an argumentative moment in which "the dense and moralist cigar-smoking reactionary bourgeois can transform him- or herself into a free-floating agnostic bohemian, moving opinions, capital, and networks from one end of the planet to the other without attachment" (p. 231). In the context of his discussion regarding the polarity of terms that comprise the modern constitution, Latour's point is to develop a corrective re-articulation of critical inquiry in which the depth analytic engagement with situated contingency is reinvigorated by a realist rhetoric. The realism Latour advocates here, however, is distinguished from that entailed by a straightforward assertion of fact (along the lines of deconstruction's opposite moment) in that it remains reflexively cognizant of its own contingency. Thus, the re-configuration of critical inquiry would not employ the argumentative maneuvers of a depth analytic critique in a strictly exclusionary fashion, but rather would seek to undercut the resistance to demands for accountability that deconstructive depth analysis otherwise entails through the simultaneous warranting of the argumentative potential that factual accounting makes available. Where efforts to suspend definitive judgement in the face of environmental degradation take place, such arguments are to be countered with factual accounts calling for specific policy planning action. Facticity and contingency are to be considered for their effects, as resources marshalled in the reflexive awareness of their mutually coimplicative, yet paradoxically, mutually exclusive nature. In essence, Latour is calling for the suspension of that feature of the modern constitution in which the relationship between fact and fetish, assertion and deconstruction, are obscured. He refers to this hybrid rearticulation between fact and fetish with the neologism "factish" (Latour 2000).

My purpose in this paper will be to explore a particular moment in the transformative relationship between the polarities that Latour discusses by considering the domain of argumentation surrounding the notion of conspiracy theory (CT). More specifically, I wish to consider the way in which depth analytic critique on the one hand, 
and the assertion of fact on the other, are involved in the accusations and counteraccusations surrounding pronouncements about CT. As we shall see, these two argumentative gestures are related to the reflexive engagement that speakers/writers display in the responsively-oriented nature of their own arguments as a constituent of dialogue. In other words, in referring to someone else's argumentative version as a CT, a speaker/writer employs the self-same kind of deconstructive, depth analytic reading which the account so referred to (as CT) is itself said to employ. In this way, it comprises a reversal or subsequent critique of that initial critique, employing the same deconstructive, anti-fetishist technique of which that initial account is said to be an example. Where this reversal takes place, subsequently asking what one then means when he or she employs the gloss of CT again inverts the polarity of the already twice reversed anti-fetishist gesture. Fact and fetish hold the potential continually to occasion one another in an infinite succession formulated around the notion of CT.

\section{Formulating prior explanations}

In order to explore how all of this relates to the points Latour explores, let us begin by considering an extract of talk taken from the transcript of a regularly scheduled press conference with the British Prime Minister, Tony Blair. The exchange represented below took place on 26 February 2004 in the wake of allegations made earlier that same day by a former cabinet minister of the Blair government, Clare Short, the substance of which was to identify the Blair government as having routinely engaged in espionage at the United Nations. According to Short's account, spying at the UN was particularly prevalent in the period immediately leading up to the British and American attack on Iraq, when those governments were seeking to pass a resolution through the Security Council authorizing their use of force to bring about a change of regime in Baghdad. In his introductory remarks prefacing the fielding of reporter questions, Blair opens by stating that he will not discuss the details of intelligence operations, citing the precedent of previous governments and the common policy of other nations in maintaining silence with respect to details of covert activities relating to state security. Against this background, the following exchange took place in the question-and-answer session (reporter question indicated with Rep, Prime Minister's response with Blair, see appendix below for fulldescription of transcription conventions employed here and in subsequent extracts to follow):

\section{Extract 1}

1 Rep Won't some people conclude that you are hi:ding behind the cloak of national 2 security in order to protect in the $\uparrow \mathrm{e} \downarrow$ :nd what is $\uparrow$ yo $\downarrow$ u:r political reputation?

3 Blair Absolutely. That- that's- I've got $\uparrow$ absolute $\downarrow$ ly no doubt that the conspiracy 4 theorists will be out there u:m saying it's all som:e terrible plot, um and saying 5 what they have been saying all the way through. Because it is the case right from 6 the very beginning $>$ in respect of Iraq < that some people cannot understand it is 7 possible to have a le $\uparrow$ gitimate disagreement about whether it was right to go to 8 war or not, now I happen to believe it was right, others believe that it was wrong, 9 and they hold those views deeply and sincerely as I hold mine. It is not necessary to have this disagreement in the context of allegations of conspiracy, wrongdoing, 
11 misconduct, lying, you can simply take it that there is a disagreement. So I've no

12 doubt at all Mick that people will be making those allegations, u:m and y'know

13 what I have discovered over a considerable period of time is whatever I say they

14 will make them

Among the first and most obvious features to note about this exchange is the way in which the reporter question is broached as giving voice to the concerns of non-present third parties - as relating to what "some people" might conclude from the Prime Minister's remarks (lines 1-2). This way of formulating his question is a characteristic feature of talk in broadcast news settings where reporter contributions are oriented to foreclosing an interviewer's individual accountability for having implicated some principal (here, Blair) in accusations of culpability potentially entailed with the question (see Hutchby and Wooffitt 1998; Clayman and Whalen 1988; Schegloff 1988). In broaching the question as a matter of what some others may conclude, the reporter attends to the potential for his query to be taken up as involving personal attack on his part.

This same feature is then neatly and elegantly picked up in the Prime Minister's response, wherein he addresses not the substance of allegations implied with the reporter's question, but the ostensible concern for the motivations of those who would query the reasons given for his silence. The same gesture by which the reporter gives voice to a depth analytic reading designed to "uncover" or "reveal" some underlying reasons for silence is itself subjected to a deconstructive, depth analytic reading. Blair imputes those same efforts on the part of the unnamed, third parties to the sinister motives of undercutting the basis on which to engage in open-ended dialogue ("Because it is the case right from the very beginning $>$ in respect of Iraq $<$ that some people cannot understand it is possible to have a le $\uparrow$ gitimate disagreement about whether it was right to go to war or not, now I happen to believe it was right, others believe that it was wrong, and they hold those views deeply and sincerely as I hold mine", lines 6-10). This argumentative manoeuver is significant for a couple of different reasons. For one, it means that the selfsame analytic gesture by which motivation is initially imputed to the Prime Minister is itself available to the Prime Minister as a resource to undermine the critique involved. The gloss on such efforts as arising from the predisposition to seek out hidden machinations (i.e., "conspiracy" (lines 3-4, 9-11) is one that entails an argumentative tu quoque which depends for its effectiveness on the use of the very techniques it seeks to undermine (see Ashmore 1989).

Critical deconstruction of some prior account thus entails asserting the facts of that account as motivated by ulterior, otherwise obscured considerations. Thus, Blair's contribution here is such that he appeals to the very principles made available in the reporter question as a way to undermine the fact of motives underlying the deconstructive critique which that reading would otherwise afford. ${ }^{1}$ In other words, by

1 The initial reference (by reporters) and subsequent reworking (by the Prime Minister) of the way "some people" draw conclusions corresponds loosely to what, in classic rhetorical theory, is referred to as argumentum ad populum. Douglas Walton discusses this sort of argumentative gesture at length in his writing on the place of emotion in argument (1992: 65-103). Like the tradition of work in argumentation theory to which his writing is a contribution (cf. Van Eemeren and Grootendorst 1992), Walton seeks to develop a normative model in which the identification of logical fallacy constitutes the basis for prescriptive correctives to the conduct of dialogue and debate. Essentially, work in 
referring to the legitimacy of disagreement (an assumption on which the broaching of the reporter query is dependent), the Prime Minister's remarks effectively suspend the demands for a definitive account. In operation here is that shifting which Latour refers to as the fetishizing of the debunking, anti-fetishizing gesture - the attribution of some structural cause (viz., CT) to ones critical efforts at uncovering the projection of motivation (viz., precedent and a policy of silence regarding matters of state security). Depth analytic critique is thus undermined on the basis of the same treatment it metes out. Just as Blair's account gets reified as the fetish concealing the "real" reason evaded in his answer, so too Blair's formulation reifies the anti-fetishizing gesture to which it is a response.

This reflexive potential effected in the Prime Minister's response is a feature of argumentation entailed by the dual character of terms which Latour identifies as making up the modern constitution. Both the anti-fetishist critique of a depth analytic gesture and the projection of a causal grounding whereby the social "facts" giving rise to such critique (as the effect of structural interpellation) are two different argumentative gestures whose variable and selective use characterize the modern constitution. In providing the materials that undergo transformation (or "translation", to use Latour's term) from one such gesture into its opposite, fact and fetish drive the engine which is the discourse of modernity (see also Latour 1993, esp. pp. 29-43). Latour, however, sees this transformation as debilitating to the possibilities otherwise made available with critical inquiry (Latour 2004a: 232, emphasis in original):

[W]hile the Enlightenment profited largely from the disposition of a very powerful descriptive tool, that of matters of fact, which are excellent for debunking quite a lot of beliefs, powers, and illusions, it found itself totally disarmed once matters of fact, in turn, were eaten up by the same debunking impetus.

Latour's answer to this impasse is to advocate the adoption of a re-worked realism, one which entails a recognition of this mutually co-implicative relationship between fact and fetish. This would then, according to Latour, provide the grounds upon which to formulate matters of "shared concern".

For our present purposes, we might note how Blair's own remarks here can be described as similarly oriented to that same objective, given that he directs his remarks to the concern with dialogue and the airing of differences in opinion ("some people

argumentation theory involves identifying, categorizing and cataloguing potential lines of defeasibility that particular arguments entail (with practitioners making use of, and sometimes extending, analytic systems from ancient traditions of rhetorical analysis), and then singling out as fallacious some set of arguments among those which are so identified. In contrast, the approach adopted here is one that begins from the assumption that all arguments - indeed, all claims of any sort - are, in principle, infinitely defeasible; and that it is the business of social actors to establish the practical limitations of that defeasibility in the ongoing course of their conversational interaction (Garfinkel 1967, 2002, see also related discussion in Edwards 1997). Thus, rather than approach the text and talk in such a way that requires the analyst to decide upon what does and does not constitute fallacy as such, the approach adopted here is one in which that question is examined for how the accusation of fallacy (either explicit or implicit) features as participants' own business. Where argumentation theory seeks to intervene in an order of business to which it is not a party, the analysis here sets out to examine the elegant and creative ways that social order is eminently created in and through such activity. 
cannot understand it is possible to have a le 个gitimate disagreement about whether it was right to go to war or not", lines 6-7).This is of interest here precisely because it is invoked in a setting where depth analytic critique and the counter-assertion of social fact accounting for such critique take place. ${ }^{2}$ Blair's advocacy of common or shared concern here thus features as a clarion call which resists the suggestion that disagreement is somehow illegitimate (lines 7-9). In other words, where agreement is the basis of legitimacy for representative action (as implied where personal motive is imputed to the Prime Minister, lines 1-2), what gets made problematic is the assumption that legitimacy can be derived independently of such consensual agreement. In glossing the critique voiced by the reporter as CT, Blair expresses the same concern raised by Latour in order to undermine the foundation on which alternative terms of agreement might be developed (e.g., that it was not right to go to war, or rather that the decision to go to war necessarily depends on popular consent for its legitimacy rather than upon governmental initiative undertaken independently of such warrant). Suspending the depth analytic gesture works here to assert the legitimacy of disagreement, to close-off from consideration any avenue of discussion where the relationship between legitimacy and popular sanction of governmental action might otherwise be formulated.

\section{Reflecting on conspiracy theory}

So far, we have examined how the terms of dialogue are at issue both in efforts to debunk, and in the work to suspend such debunking efforts as realized in accusations of CT. Now in this section, I want to consider how CT accusations are themselves either further substantiated or undermined, both in the debunking of the assumptions that are said to inform CT, and in the argumentative placement of such debunking efforts as a responsive gesture to some prior argumentative position. As we shall see, these factors relate to the terms of the modern constitution in Latour's observations by touching on the process in which fact and fetish mutually entail one another. Accusations of CT are themselves made to provide the grounds for further rhetorical modification, for subsequent argumentative struggle. They are themselves the site of elaborative reworking, just as (in Blair's formulation) the accusation of CT re-works the deconstructive techniques it glosses as conspiratorial.

\subsection{Detailing conspiracy}

The detailed specifics of what is involved in theorizing conspiracy are not explicitly spelled out in Blair's own account of what he takes CT to be. Rather, the Prime Minister's gloss on the critique given expression in the reporter's question is sufficient to

2 Resolving the contradiction between the two is, in some sense, constitutive of that occasion. After all, the ostensible business pursued in the press conference is, among other things, the work of clarification realized in and through the assertion of government accounts and their resistance to deconstructive readings offered up in reporter questions. For further discussion of this same material, see McKenzie (in submission). 
dismiss the related allegations on the grounds that they are both predictable and resistant to reasoned argumentation ("and y'know what I have discovered over a considerable period of time is whatever I say they will make them", lines 13-15). ${ }^{3}$ Now, in contrast to Blair's talk, in accounts where the actual details of what is involved in accusations of theorizing conspiracy are made to feature, the details of supposed conspiratorial activity are often related to the implications entailed in the account glossed as CT. In other words, the details of conspiratorial machinations are related in an account of CT as a way of undermining that account's claims. The demands for accountability entailed in the explanation glossed as CT are dismissed as outlandish, unsubstantiated or otherwise implausible. So, for example, consider the following exchange in which two speakers - a social science interviewer (Int) and a junior-level, U.S. diplomat (AmDip) - discuss the diplomatic and political activities which took place between the United States and Iraq in the period immediately preceding the Persian Gulf War of 1991.4 Here, the response of the American diplomat is directed at elaborating the details of possible explanations for U.S. involvement which he seeks to discredit as CT. This all takes place in the context of a discussion about the various explanations for the U.S. decision to pursue military conflict with Iraq, with the issue of diplomatic initiatives and continued economic sanctions being considered as alternative courses of action precluded by the U.S. decision to pursue armed confrontation (see also related analyses in McKenzie and van Teeffelen 1993; McKenzie 2001). Against this background, the discussion turned to the question of what interpretations were to be made by Iraq of the U.S. diplomatic initiatives in the period immediately preceding Iraq's invasion of Kuwait on 2 August 1990, where U.S. diplomatic activity during that time was seen by some as providing the basis for Iraq to infer U.S. support for its aggression vis-à-vis Kuwait. ${ }^{5}$

\section{Extract 2}

\begin{tabular}{|c|c|c|}
\hline 1 & Int & $\begin{array}{l}\text { Yeah, I mean most of the criticism is uh- you know, of- of uh- US sort of } \\
\text { intervention, >I'm not quite sure what to call it, < but uh- for lack of a better term } \\
\text { at the moment, intervention in the- }\end{array}$ \\
\hline 4 & AmDip & Yeah. \\
\hline 5 & Int & in the situation, would cite things like um- the diplomatic contact with Iraq just \\
\hline 7 & AmDip & $\begin{array}{l}\text { before- just prior to the war, [1 mean, ] and so there's the- the "green light" idea, } \\
\text { [Yeah.] }\end{array}$ \\
\hline$\varepsilon$ & $\begin{array}{l}\text { Int } \\
\text { AmDip }\end{array}$ & $\begin{array}{l}\text { you know, that the [[United]] States uh- diplomatic messages were giving a } \\
\text { [[Right.]] }\end{array}$ \\
\hline
\end{tabular}

3 To a certain extent, this is a function of the formulation's having been made in a press conference where dialogue occurs within the constraints of the single turn, question-and-answer format which constitutes the occasion.

4 This material was originally recorded as part of an investigation into the explanatory practices by which American and British expatriate residents of the Middle East make sense of Western involvement abroad (McKenzie 1998).

5 For one discussion of the so-called Glaspie Affair relating the diplomatic incident to which this refers (involving U.S. Ambassador April Glaspie), see Mahajan 2003: 125-126. 
10 Int green light to Iraq, that um-

11 AmDip Right.

12 Int you know, the United States would not uh- I don't remember the wording

AmDip Yeah.

Int you know, "Would take no position in" uh-

AmDip Right. [Uh- u:h- inter-Arab]

Int [you know that sort of $\mathrm{xxxx}-$ ] $\mathrm{x}$.

AmDip conflict.

Int Right.

AmDip Yeah. Well again, I really can't discuss anything like that in detail but, you know, the question that- I know a lot of people who've put that forward to me asking us, "What did Iraq get out of it". I mean, if- if there was a deal made with Iraq, you know, what, the deal was that we would come and bomb Baghdad? I mean, well what- what benefit did Saddam Hussein expect from, you know, well- well- well- well what- when the- when the thing- the deal was cooked up, you know, >as these conspiracy theorists would have it, < presumably Iraq was going to benefit from it, it was going to get something,

Int Mm. [xxx-]

AmDip [And we would] get something too. And I'm not even sure what, you know, uh- it just seems, you know, way- that- you know, there was way too many factors that would have to fall into place that normally don't when people intend them to. I mean just the way the world works, if you plan something that intricate, it almost never works.

Int Well I mean the- the cricicism was that the- you know, that the United States basically uh- wanted Iraq to be in this position as a pretext to attack, you know, and that it would insure US

AmDip Yeah.

Int u:h- you know, com- US control, >in a sense < over the region, but uh-

AmDip Well a lot of people say, you know, do- do we need it? I mean, does that-

Int Yeah.

AmDip are we going to be in that much better a position now than we were before? Uhyou know, what- what- what is it- uh- I just don't see it translating into any real advantage,

Int $\mathrm{Mm} \mathrm{hm}$.

AmDip you know, I mean sending five-hundred thousand people across the world and then pulling them all out,

Int Yeah,

AmDip it's- you know, and- and again just >completely off the record, just personally< it's not going to get Bush re-elected, you know, I mean if you- he's going to have to fight for his election this year.

Int $\mathrm{Mm} \mathrm{hm}$.

AmDip It's not going to help u:h- it- you know, it certainly hasn't helped Iraq, it- it's justyou know, I- I don't see: any motive being strong enough for people to sit down and work out that devious a scheme and then pull it off, because you have to- it's not- it's like the people who say- you know, I've had people tell me, you know, u:h- that uh- you know, there's this whole intricate theory about how the United States planned to have the Shah overthrown, you know, that Khomeini was basically the result of, you know, CIA intervention and- and all this stuff. It's like "Well", u::h- you know, "why". Or that, you know, the US had, you know, Zia ul-Haq killed in Pakistan. I mean, this- this is the part of the world that conspiracy theories are the norm. You know, that the- the:- in the US they certainly occur, you know, there are people who believe in very intricate theories and occasionally there is some truth to them, but in- most of the time it's not. Most of the time, you know, accidents and misunderstandings play a lot- 
much larger part of events than, you know, these Byzantine conspiracies, uha:nd- but here, you know, when you- when you- I talk to- a lot of the time, you know, the conspiracy comes before: the: sort of rational thinking of- of the process. Or even the uh- understanding of the event. You look at who benefit- or who's se- seen to have benefitted and then you work backwards to see who must have done it,

Int $\mathrm{Mm} \mathrm{hm}$.

AmDip and I just don't think- that's just not the way- that's not the way we- we operate. Int $\mathrm{Mm}$.

AmDip I mean, God knows, even if we wanted to, we just can't pull off things like that. Or it's very very rare that anything-that happens.

This is, of course, a rather lengthy passage involving a great deal of different interactional business, not all of which we have space to consider here. For our present purposes, however, there are at least two particularly noteworthy features of this talk. The first of these takes place where the diplomat recounts the details of what the supposed objectives of a conspirational initiative might entail. In addressing those specifics, he formulates a set of inferences which are easily undermined as both implausible and unsubstantiated by the evidence of subsequent events. Thus, the diplomat reads the interviewer question concerning diplomatic contact between the U.S. and Iraq as implying several different things: That Iraqi collusion featured as essential to the U.S. military campaign in order to benefit the Ba'athist regime of Saddam Hussein (lines 23-28), that the risk to U.S. troops was of potential benefit in garnering widespread support for the re-election ambitions of George Bush, Sr. (lines 49-51), and that the 1979 overthrow of the Pahlavi Dynasty in Iran was orchestrated by U.S. efforts (lines 56-59). The facile, broad-ranging treatment in at least some of these formulations not only makes the position they are meant to describe seem extreme, but also renders them resistant to objection giving that raising such opposition would require additional interactional work on the part of an interlocutor (here, the interviewer) to initiate repair to the interviewee's contribution. The combination of argumentative detail here, together with both the general direction of the argumentative trajectory as well as the sheer proliferation of cases, means that opposing the thrust of the speaker's argument is a much more labor intensive undertaking than it might otherwise be were, say, the talk constitutive of some other sort of conversational encounter (Osborne and Rose 1999). As with the talk we examined in the Blair press conference, so too here the joint production of the dialogue within the constraints of the question-and-answer format mitigates against the initiation of just such repair work (Hutchby and Wooffitt 1998: 145-171). In other words, both the interviewer and the interviewee are here oriented to providing for the relevance fo their respective entitlements to address the substance of the depth analytic reading, such efforts being productive of their different roles in the encounter. This is not here a matter of the diplomat's category entitlement as a government representative providing the warrant for him to elaborate on such details in the way that he does (especially since neither speaker makes anything of that membership status in the talk at this particular juncture), 6 but rather of his status as

\footnotetext{
6 Providing for that entitlement could take the form of a speaker, say, making relevant his or her category membership as diplomatic representative. This is an activity which these speakers jointly undertake at other places in this same interview, but which they do not pursue here. To the extent that they
} 
knowledgeable party as provided for in the specific setting where he is the queried participant - the one who "goes second" in an argument and who is therefore in a position to challenge the point made by the interviewer as well as to choose if and when to counter with an alternative (Sacks 1992 vol. 2: 348-353, discussed in Hutchby and Wooffitt 1998: 164-171). Together these factors mitigate against challenging the interviewee's contribution, even if they do not determine the account ultimately to emerge from the encounter.

Note too that the diplomat's fomulation of a second-go contribution here itself involves foreclosing an argument from consequences (or argumentum ad consequentiam, cf. Walton1996: 168-207, 1992: 165-170; Van Eemeren and Grootendorst 1987: 289). Thus, with the implicit claim that U.S. activities in the Gulf War realized no benefit to either American or Iraqi interests (lines 39-43), he works to counter the potential to infer a motive account which such an outcome would otherwise make possible. Furthermore, where the proliferation of detailed specifics mentioned above entails the presentation of multiple cases (again, so that where one case might be seem inconclusive, their cumulative effect is resistant to being undermined), this involves his addressing only those particulars which are of no practical advantage rather than pursuing the argumentative trajectories that would otherwise be opened up by the interviewer's initial query. Indeed, the diplomat's efforts along these lines are occasioned by the interviewer's own work to detail potential critique of U.S. actions (lines 16-20). However, the outcome of the diplomat's second-go positioning here is to direct interpretative efforts in elaborating the interviewer's initial query within the limited scope the he, the diplomat, elaborates. This is particularly elegant because it means that both cases - that which the diplomat works to undermine and that which he provides for - involve formulating an argument from consequences. The difference is in how the speaker substantiates one set of events as the outcome over another.

This selective provision for an argument from outcome is further elaborated where the diplomat provides the grounds to infer a theory of unintended consequences. 7 The inference here is that the interpretation of events glossed as CT does not allow for the development of eventualities unaccounted for by the theory of motives they are said to make available. In other words, the actual unfolding of events is said to exceed what

are oriented to providing for entitlement here, this pertains to their status as interviewer and interviewee category roles they are oriented to through, among other things, the production of the talk in the questionand-answer format.

7 The relation to Giddens' work on structuration theory and the affiliated notion of unintended consequences is of interest here (see Giddens 1984). While it is beyond the scope of this paper to discuss at length, we might note how Giddens' observations are made to operate in Third Way political formulations oriented to obviating the demand for accountability for the consequences of policy initiatives (see Giddens 1994, 2002; Callinicos 2001). Sociological theory regarding the notion of unintended consequences can be related back at least as far as the Scottish Moralist heritage of Adam Smith and David Hume (see related discussion in Abrahamson 2001: 141-151). With regard to the impact of Scottish Moralism on sociological theory, Abrahamson remarks: "The Scots' separation of intent and consequence proved to have enormous analytical and methodological implications. It meant that social practices could not necessarily be judged according to any intrinsic or introspective standard that involved people's motives" (2001: 142). Here we merely note the way in which such speculation is made to bear in argumentative settings like those documented here. 
is predicted in the CT ("Most of the time, you know, accidents and misunderstandings play a lot- much larger part of events than, you know, these Byzantine conspiracies", lines 81-83). On that assumption, the speaker is able to discredit deductive processes by which motive might otherwise be inferred ("You look at who benefit- or who's se- seen to have benefitted and then you work backwards to see who must have done it, and I just don't think- that's just not the way- that's not the way we- we operate", lines 86-91). The speaker can thus attribute to U.S. actions a set of forthright motives otherwise called into question in the account dismissed as conspiratorial. This is of particular interest to our discussion of Latour since it involves bringing to bear an assumption of devious, opaque mode of operation on the part of those whose formulation is glossed as CT in order to render its own claims of straightforward transparency intelligible. That is, it paradoxically employs a reifying formulation of a depth analytic mode of analysis in order to counter the effectiveness of a depth analytic reading.

\subsection{Conspiracy vs. opportunism}

In Latour's remarks regarding the argumentative use of depth analytic and realist interpretative practices, he highlights the complimentary nature of the two as each providing the grounds for the undermining of its respective alternative. Realist readings (of facts) are countered with depth analytic readings (of fetish) which highlight the contingency of the facts so produced. In turn, this depth analytic gesture is countered with an assertion of the autonomous facts (often glossed as "social structure", “ conditions of possibility", etc.) by which they are determined. As we have seen in the material above, arguments by which motive is imputed are undermined on the basis that they themselves attach to some predictable, determinate action on the part of the speakers (as in the extract from the Blair press conference where the Prime Minister remarks on the inclination of people to make allegations, lines 12-13; or as in the interview with the American diplomat where the imputation of cause is said to arise independently of and prior to any consideration of some event's details, lines 66-70). The explanation of some event offered up in an account is always subject to the selfsame deconstructive technique it employs.

In addition to noting these features of talk, I have also noted in passing how such undoing of depth analytic critique operates as a feature of argumentative positioning between first and second turns in an argumentative encounter. Elaborating on this point, Hutchby and Wooffitt remark (1998: 167, emphasis in original):

As Sacks observed (1992 vol. 2: 348-53), arguing about opinions is a basically asymmetrical activity, in whatever context it occurs. There are significant differences between, on the one hand, setting out an opinion, and on the other hand, taking issue with that opinion. Sacks described these actions respectively as 'going first' and 'going second' in an argument. Sacks proposed that those who go first are in a weaker position than those who get to go second, since the latter can argue with the former's position simply by taking it apart. Going first means having to set your opinion on the line, whereas going second means being able to argue merely by challenging your opponent to expand on, or account for, his or her claims. Thus, while first position arguers are required to build a defence for their stance, those in second position do not need to do 
so, and indeed are able to choose if and when they will set out their own argument, as opposed to simply attacking the other's.

Argumentative effectiveness thus entails work by interlocutors to position their particular formulations as second-go contributions. Where the (re-)assertion of depth analytic readings over and above structural, realist accounts occurs, this involves a second-go reformulation relative to which such critiqued accounts get situated as firstgo arguments.

Another example of this second-go reformulation appears in Rahul Mahajan's book Full Spectrum Dominance (2003), in which he addresses the objectives and motives for continuing U.S. involvement in the Persian Gulf. In his extensive and detailed account, Mahajan builds the case for a view of U.S. foreign policy as motivated by objectives first spelled out in the immediate aftermath of the Second World War, wherein the United States acted to maintain a position of global dominance through strategic control of the oil reserves on which the rest of the world's economy depended (and still depends). Crucial to the development of Mahajan's argument is its second-go placement, as a response to "mainstream political discourse [which asserts] that any intimation that oil might have something to do with the war is immediately branded a "conspiracy theory"' (p. 163). 8 The development of his responsive argument here involves the re-assertive, second-go placement of a depth analytic interpretation. This is so not simply because it entails the use of inference in extrapolating from the text of foreign policy documents - the Cold War policy statements of U.S. foreign affairs architect, George Keenan (see also related discussion in Chomsky 1992) - but also because his book is situated as a response to arguments that the U.S. military presence in Iraq was established to promote the development of democracy in the region and of insuring respect for human rights and the defense of various humanitarian interests. In Mahajan's account, the formulation of this latter altruistic version is regarded as necessarily self-serving to the interests of U.S. global domination. Thus, Mahajan's depth analytic reading is itself one that understands the individual agency underlying the formulation of humanitarian motives as necessarily contingent. Contingency and determinism necessarily entail each other, though their relationship (as cause to effect) gets articulated where they feature in first-go or second-go argumentative positions. This all relates to Latour's point concerning the mutually exclusive and yet mutually entailing terms of the modern constitution. While depth analyses take factual accounts as their objects of deconstruction, realist accounts assert the facticity of determining factors from which such depth analytic critique emerges (Ashmore et al. 1989). The two gestures are mutually entailing. Whichever of these two gestures is operative at a given

8 Mahajan himself remarks upon the effective status of first-go and second-go placement of arguments (though he does not use those terms) in the introductory statement with which he opens Chapter 9 of his book ("Oil as a Component of Empire", pp. 163-180), remarking that "After disposing of the various justifications given for the war, we are faced with the obvious question: What was it really about? " (p. 163); and in commenting on the CT glossing of the account connecting war with oil, he notes "This is rather inexplicable, given that even the most orthodox defenders of the status quo freely admit that economic interests shape policy" (p. 163). These remarks work effectively to place Mahajan's argument in a responsive, second-go position. 
moment is the realization of its placement as first-go or second-go constituents in an argumentative structure.

Another point to note when considering the re-assertion of depth analytic inference as a second-go, responsive gesture to the formulation of some prior argument is that the operative assumptions by which the accusation of conspiratorial theorizing is rendered effective are not themselves necessarily rejected. That is, in arguing against the CT gloss, one can reject the notion that some actions are the outcome of a set of particular conspiratorial machinations without rejecting the idea that a hidden plan of action is nevertheless still operative. The difference between the two lies in asserting the exceptionality of the case at hand. So, in Mahajan's argument, this occurs where he identifies as constituting the substance of the argument to which the CT gloss is attached the view that U.S. military involvement in the Gulf is about domestic considerations for cheap oil (see "Some Common Misconceptions", pp. 167-169). This concern to ensure a supply of cheap oil constitutes a somewhat different matter than that to which his own argument is addressed. Rather, the argument he takes up is one of how the world's oil resources are of strategic significance in geo-political affairs. In other words, Mahajan claims that the accusation of U.S. duplicity which gets dismissed as CT is different than the one he addresses. For him, U.S. involvement is not about ensuring a ready supply of cheap oil for American domestic consumption, but about controlling the global supply of oil as a means to provide a strategic chokehold on the natural resources necessary to the world's economy. Countering the CT gloss in this way, as a strawman position irrelevant to the protagonist's own argument, does not directly contest the force of the argument which inheres in the reading made available with the CT gloss. Instead, it argues the exceptionality of the particular case at hand (cf. Billig 1987: 148-185).

A second example of this same sort of formulation can be found in Greg Palast's popular critique of the American political condition, The Best Democracy Money Can Buy (2003). In the passage reproduced below, Palast formulates a responsive argument to a position he identifies as constituting a prior accusation of CT. This passage appears following an extended discussion of the irregularities in the procedures of the U.S. Presidential election of 2000 which brought George W. Bush to his first term in the Oval Office. At issue throughout that discussion is the disenfranchisement of large sectors of Democratic, primarily Black, voters from participation in what turned out to be the key electoral constituency of the State of Florida. There, residents suspected of having a felony record were purged from the list of eligible voters under a provision of state law. With the use of a computerized voter registration database wherein those voters showing similar personal details to convicted felons were themselves counted as having felony records, a significant number of otherwise eligible Democratic voters were barred from casting a ballot. This passage appears under the section title "New Unreported Evidence: Wrong is Good, Right is Bad" (2003: 51, emphasis in original):

I now began to understand the brilliant deviltry of the purge game. It did not matter if, on Day One of the purge process, Republicans had some grand plan, some elaborate conspiracy, to eliminate the vote of AfricanAmerican innocents. Rather, document after document suggested that, once the operatives saw the demographics of the raw lists - tens of thousands of names of mostly Democratic voters - they moved heaven 
and earth to prevent its reduction. A list of 57,000voters, mostly Black, erased with the flick of a switch was just fine with Mr. Roberts [Rep., Director of Florida's Division of Elections] and crew. Make verification phone calls? Have statisticians check the findings? Correct the methods? Why, that would only cut the list . . . by 90 percent at least. Why should a Republican administration pay for that?

It's not "conspiracy," but opportunism. The department of Elections Republicans began to act like a bank customer who accidentally receives a million-dollar deposit that is not theirs: To fail to correct the error, to actively conceal the error, is theft in any court. Only here the crime was far bigger: The theft of our democracy.

Opportunism does not require planning and conspiracy; it does require a cover-up. In any investigation, I try to imagine myself in the perps' shoes. If I had a magic list falsely accusing my opponents' voters of crime, how would I prevent the discovery that it is bogus? First, don't verify the list; not one phone call. Second, don't correct the methodology: Ignore every warning about crap inputs, crap methods, crap results. And third, for God's sake, don't allow any independent statistician near it.

This passage involves the rather elegant marshalling of argumentative resources whereby Palast highlights the outcome of some chain of events over the motive account entailed with the CT gloss. Thus, where Palast starts out here by remarking on the irrelevance of premeditation ("It did not matter if, on Day One of the purge process, Republicans had some grand plan, some elaborate conspiracy"), his doing so works to counter the argumentative assumptions in which only intention implies accountability and where the imputation of intention is accomplished by establishing a connection between the initiation of events in a series of related events, the outcome of which is predictable. Here, the issue of whether the database problem was known about beforehand is treated as irrelevant to the consequentiality of events in the series. That is, the demands for accountability are not related to pre-planning, but to the outcome of a series of actions if and where that outcome was predictable once that series of events had been set in motion. A relationship between intention and consequentiality is rejected as the exclusive condition of responsibility for voter disenfranchisement. By managing the relationship between intentionality and consequentiality in this way, Palast works to foreclose whatever appeal might be available to a theory of unintended consequences. Palast's argument emerges here because he isolates the initial cause in the series of events, and then attaches intention to the subsequent events in the series leading up to the final outcome.

Intention, and more specifically the demand for accountability it entails, is reintroduced through this specification of related events in a causal chain. In this way, Palast warrants the very assumptions otherwise resisted in and through the accusation of CT where the assumption of foreknowledge or pre-planning is crucial. He is thus able to hold Bush administration officials accountable for the effects of their actions without imputing motive. This gets more fully elaborated with his analogy of the bank deposit error ("The department of Elections Republicans began to act like a bank customer who accidentally receives a million-dollar deposit that is not theirs: To fail to correct the 
error, to actively conceal the error, is theft in any court"). By means of this analogy, Palast is able to counter the dismissal entailed in the CT gloss by suspending the key assumption of pre-meditation that it might otherwise involve. His contrastive gloss on this as cover-up ("Opportunism does not require planning and conspiracy; it does require a cover-up") neatly indexes this distinction. ${ }^{9}$ Noteworthy throughout all of this is the varied way in which depth analytic and realist arguments are deployed and countermanded such that the basic opposition between them is not suspended, but rather features as mutually co-implicative. One term occasions its opposite, and that opposite occasions the use of the first term to which it is itself a response.

\title{
4. Conclusion
}

In exploring the data extracts that we have considered above, my objective has been to consider argumentative moments glossed with the term conspiracy theory as occasions wherein the different, competing and yet mutually entailing terms of understanding that characterize modernity are brought to bear. In each of the examples we have considered, this mutually entailing feature of the terms are obscured. As Latour remarks (2004: 240214, emphasis in original):

\begin{abstract}
Antifetishists debunk objects they don't believe in by showing the productive forces of people; then, without ever making the connection, they use objects they do believe in to resort to causalist or mechanistic explanations and debunk conscious capacities of people whose behavior they don't approve of. The whole rather poor trick that allows critique to go on ... is that there is never any crossover between the two lists of objects in the fact position and the fairy position.
\end{abstract}

This same aspect of obscuring the connection is what concerns Latour in his discussion of the argumentative moment where consequentiality and motive are disconnected (a position entailed in the Third Way rhetoric of Tony Blair's New Labor Party and its scholarly champion Anthony Giddens, see Blair 1998; Giddens 1984, 1994, 2002; Weltman 2004). If the premeditated intention cannot be shown, then the argument implies, one is not accountable. Within the modern constitution, motive is crucial; and, of course, attaching action-to-outcome (or the failure of action to prevent foreseeable outcomes) is the characteristic of explanation in which the connection between accountability and intentionality are replaced with a strategic realism. In other words, the decision to maintain or replace some policy is not, for Latour, made with an appeal to motive, but to outcome. The proviso in Latour's approach (and a crucial aspect that differentiates it from the sort of argumentative work Palast undertakes), however, is that efforts to suspend a realist explanation are themselves subject to the same depth analytic reading which they themselves depend upon for their own effectiveness. That is, in great part, the implication of his own suggestion for a re-worked realism: It entails not a suspension of the different terms which make up the modern constitution, nor the advocacy of any one term over its alternative (the realist over the contingent/depth

9 A similar line of argumentation, of course, attaches to a legal judgement of criminal negligence. 
analytic), but rather the recognition of the mutual entailment between the two. It is within this idiom that Latour stakes out the grounds for an amodernity, arguing that we have never been modern (Latour 1993). This gesture on his partis one that seeks not to escape or transcend the terms of the modern constitution, but to extend them in the interests of formulating further, creative argumentative positions which translate between the terms of the modern constitution to bring about hybrid formulations (see also Latour 2004b). What I have tried to show in this paper is how the accusation entailed in the gloss CT and its management themselves involve this very sort of creative translation between the terms of the modern constitution.

As an exposition of the contradictions of the project of modernity, Latour's own work is certainly stimulating and offers a refreshing treatment of the issues involved by way of analytic work in the sociology of scientific knowledge and science and technology studies. Latour's own approach here is itself ambivalent because while he advocates the formulation of hard-nosed, realist arguments in which the "facts" of the matter are asserted against the equivocating uncertainty entailed by a critical emphasis on the contingency of accounts, he tempers this with a move to point up the fragility of such factual, realist accounts. He seeks to allow for a hybrid space where the insights of depth analytic critique are denied to the argumentative opponents who would employ them to suspend decision making but which are nevertheless available to inform his own advocacy of actions implied by the facts of the matter described in his own, re-worked realism. Among other things, this means that Latour can offer no principled criteria with which either critical or realist arguments are to be employed. His seeking out of a hybrid space does not constitute an assertion of the "facts" of the matter, but rather constitutes the advocacy of realism as an argumentative strategy whose use is to be selectively applied where appropriate to ones goals of countering critique.

For an audience of critical theorists whose argumentative arsenal consists of a one-weapon stockpile, such a move undoubtedly constitutes a welcome corrective. In Latour's writing, he takes great pains to explain the relationship between critique's argumentative moment and its association with its realist alternative as constitutive of modernity. Where Latour's approach falters, however, is perhaps in his efforts to achieve an argumentative moment that simultaneously encompasses both of modernity's gestures. The assumption seems to be that by making visible the relationship between fact and fetish which is otherwise obscured, this would provide the basis to engage in dialogue on a different footing, as it were. Moving away from the way in which the modern constitution operates would entail the simultaneous awareness and appropriation of argumentative gestures which are otherwise regarded as antithetical and mutually exclusive. To employ a computer metaphor here, Latour seems to be advocating a strategy of parallel processing in order to solve the limitations of a linear approach. The difficulty with all of this is that argumentation itself turns out to be a linear undertaking. In the examples I have presented above, I have tried to show how speakers/writers employ the different modes of argumentation that Latour identifies as responsive gestures to their opposite values. Where this involves accusations of conspiratorial theorizing, critique is transformed into realism and back again. An accusation of CT renders its prior turn a fetish whose claims to facticity it unmasks, and responses to $\mathrm{CT}$ renders its prior turn a fact whose claims to uncover fetish are determined by the autonomous circumstances from which they arise. The two modes of 
argumentation seem clearly evident in these examples. Yet, how the two modes could be simultaneously realized in actual argument in just the way that Latour seems to advocate is not at all clear. 10

As a meta-formulation with which to theorize the constitution of modernity, Latour's work is brilliant; but as a practical strategy for pursuing political advocacy, its relevance is limited to a cataloguing of the argumentative resources available to proponents of various positions. Latour does not, and cannot, tell us how to operate in both modes simultaneously, nor does he offer us, through his programmatic metatheorizing, a way of deciding upon the merits of some issue under discussion. In the example he mentions (relating to environmental degradation), he can offer us no principled way to decide the merits of the case for modification to existing environmental policy where the question of the reliability of scientific evidence is opened-up to discussion, except to assert the facticity of the evidence which the related scientific findings formulate. This may or may not well be effective in countering the argumentative efforts of those who would seek to suspend definitive judgement on environmental policy, but it hardly constitutes a movement outside of the modern constitutional framework that Latour describes. Instead, it constitutes yet another move in the linear process that defines that framework. More significantly, perhaps, it also fails to address the critical doubt raised by those who would problematize the findings of scientific research on environmental degradation. Indeed, Latour's own remarks on this involve a subtle move in which the contrivedness and self-interested nature of such critical formulations is presumed as the background of understanding that informs arguments about global warming. 11 For instance, quoting from an article in the NewYork Times (15 March 2003, p. A16), he implicitly warrants the deconstructive stance that the article's author develops (Latour 2004a: 226, italics in quotation):

\begin{abstract}
Most scientists believe that [global] warming is caused largely by man-made pollutants that require strict regulation. Mr. Luntz [a Republican strategist] seems to acknowledge as much when he says that "scientific debate is closing against us." His advice, however, is to emphasize that the evidence is not complete.

"Should the public come to believe that the scientific issues are settled," he writes, "their views about global warming will change accordingly. Therefore, you need to continue making the lack of scientific certainty a primary issue."
\end{abstract}

Note here how the New York Times author treats the Republican strategist's statements as a transparent concession to the certainty of scientific findings which he (the strategist) works to topicalize. In other words, the author fails here to distinguish between what is, for him conclusive evidence, and what, for the strategist, is given as

10 At least not from within the confines of interactional conventions of the sort by which public argumentation is characterized. This overlooks more radical alternatives, of course, such as that realized in monastic and other traditions of silence (Burke 1993: 123-141).

11 This is a feature which Alec Fisher (2004: 115-131) elaborates in the distinction he draws between an asserted and an unasserted proposition, and which Lena Jayyusi (1984) discusses in terms of opaque and transparent reference. 
uncertain. 12 The author's own critical comments on the strategist's remarks (implicitly endorsed by Latour) elide that distinction as a way for him to warrant an understanding of the strategist's reading which that strategist himself works to undermine. Here, the gloss of the New York Times author on the significance of the strategist's metaformulations is itself ambiguous ("Most scientists believe . . Mr. Luntz seems to acknowledge as much"). Are readers to understand Mr. Luntz's remarks as an acknowledgement of the facts underpinning the scientific consensus, or are they to understand those remarks as an acknowledgement of the fact of the scientific consensus itself, independently of the issue in relation to which that consensus is formulated? 13 The author is approvingly quoted by Latour in order to champion (what he takes to be) the emancipatory goals of critical-rationality over the instrumental calculations of efficiency which the article itself documents. Like the very formulations that he seeks to counter, however, Latour himself does all of this within an argumentative mode which implicitly endorses and depends upon the critical stance that he elsewhere argues for stepping beyond. ${ }^{14}$ It is not at all clear how his own formulations here manages to move outside the terms he discusses.

Perhaps a different way to approach the matter of argumentation conducted within an anti-foundational idiom would be to argue the relative merits of risk (see Beck 1997, 1999; Beck et al. 1994; Lash et al. 1996). Certainly, to do so would go some way toward stepping outside the boundaries of modernity's linear argumentation, with its exclusive insistence either on establishing the facts of the matter or enacting antifetishist debunking. However, as with the limitations encountered in set theory or in the application of a rule (Wittgenstein 1967: §440; Winch 1958; see also Edwards 1997: 126; Arrington 2001), this only puts the problem off at a step's remove, so to speak. This is so because where conceived in terms of risk, the issue then becomes one of arguing over the different assessments of that risk. Even where interlocutors might well agree on the fundamentals of some case at hand (say, that long-term survival is of greater

12 To be more exact, the Republican strategist does not inquire into the reliability of scientific findings per se; rather he comments here upon the effects that critically interrogating scientific work makes possible, in such a way that the issue of scientific certainty is irrelevant to the point he pursues. For a related discussion of the distinction between transparent and opaque reference, see Jayussi (1984) and for a discussion of the methodological shortcomings entailed by the failure to make a similar distinction between use and mention in the analysis of everyday accounts, see Potter's and Litton's (1985) critique of social representation theory.

13 Here the ambiguity of the author's remarks is perhaps productive of his own efforts to formulate the implicit claims in a fashion that attends to his own accountability for the contingency of his conclusions, where the work of objectifying those claims in a quotation devolves responsibility for either sanctioning or warranting those claims even while equivocating on that question itself (with phrasing that references what the speaker "seems" to be saying). This is a reflexive aspect pervasive to mundane formulation (Pollner 1987; Smith 1978; Potter 1996).

14 The emphasis on the conditions inherent to modernity is an aspect of Latour's work common to Frankfurt School critical theory. The classic statement here in Max Horkheimer's and Theodor Adorno's Dialectic of enlightenment (1972; see also reviews in Brown and Goodman 2001; Calhoun and Karaganis 2001). 
importance than short-term capital gain), the degree of risk attached to either of those fundamentals still remains open to continuing debate.

Nowhere does Latour's work point us to a way out of these modern constitutional limitations. While he can identify the terms of such a constitution as well as providing a picture of how it operates, this in no way substitutes for an engagement with or transcendence of that constitutional arrangement. As with playing tennis or driving a car, explaining is not the same thing as doing. So, where does all this leave us? In the spirit animating discussion in the forum to which Latour's remarks are addressed, it means choosing a position and arguing for it with all the rhetorical resources provided for within the modern constitution. Whether that position itself is subsequently formulated as a first-go CT or not depends upon the position from which it is argued as well as its persuasiveness in arresting the back-and-forth movement between fact and fetish that characterizes dialogue within the modern constitution.

\section{References}

Abrahamson, M. (2001) Functional, conflict and neofunctional theories. In G. Ritzer and B. Smart (eds.), Handbook of social theory. London: Sage, pp. 141-151.

Arrington, R.L. (2001) Following a rule. In H.-J. Glock (ed.), Wittgenstein: A critical reader. Oxford: Blackwell, pp. 119-137.

Ashmore, M. (1989) The reflexive thesis: Writing sociology of scientific knowledge. Chicago: University of Chicago Press.

Ashmore, M., M. Mulkay, and T. Pinch (1989) Health and efficiency: A sociology of health economics. Milton Keynes: Open University Press.

Beck, U. (1997) The reinvention of politics: Rethinking modernity in the global social order, trans. M. Ritter.London: Polity Press.

Beck, U. (1999) Risk society. Trans. M. Ritter. Oxford: Polity Press.

Beck, U., A. Giddens, and S. Lash (1994) Reflexive modernization. Cambridge: Polity Press.

Berman, M. (1999) Adventures in Marxism. London: Verso.

Billig, M. (1987) Arguing and thinking: A rhetorical approach to social psychology. Cambridge: Cambridge University Press.

Blair, T. (1998) The Third Way: New politics for the new century. London: Fabian Society.

Brown, R.H., and D. Goodman (2001) Jürgen Habermas' theory of communicative action: An incomplete project. In G. Ritzer and B. Smart (eds.), Handbook of social theory. London: Sage, pp. 201-216.

Burke, P. (1993) The art of conversation. Cambridge: Polity Press.

Calhoun, C., and J. Karaganis (2001) Critical Theory. In George Ritzer and Barry Smart (eds.), Handbook of social theory. London: Sage, pp. 179-200.

Callinicos, A. (2003) An anti-capitalist manifesto. Oxford: Polity Press. 


\section{Kevin McKenzie}

Callinicos, A. (2001) Against the Third Way: An anti-capitalist critique. Oxford: Polity Press.

Chomsky, N. (1992) Deterring democracy. London: Vintage.

Clayman, S., and J. Whalen (1988) When the medium becomes the message: The case of the Rather-Bush encounter. Research on Language and Social Interaction 22: 214-272.

Edwards, D. (1997) Discourse and cognition. London: Sage.

Fisher, Alec (2004) The Logic of Real Arguments. Second edition. Cambridge: Cambridge University Press.

Garfinkel, H. (1967) Studies in Ethnomethodology. Englewood Cliffs: Prentice-Hall.

Garfinkel, H. (2002) Ethnomethodology's Program: Working Out Durkheim's Aphorism, ed. A. Rawls. Lanham, MD: Rowman \& Littlefield Publishers.

Giddens, A. (1984) The constitution of society: Outline of the theory of structuration. Cambridge: Polity Press.

Giddens, A. (1994) Beyond Left and Right: The future of radical politics. Oxford: Blackwell.

Giddens, A. (2002) Runaway world: How globalization is shaping our lives. New edition. London: ProfileBooks.

Horkheimer, M., and T. Adorno (1972) Dialectic of enlightenment. New York: Continuum.

Hutchby, I., and R. Wooffitt (1998) Conversation analysis: Principles, practices and applications. Cambridge: Polity Press.

Jayussi, L. (1984) Categorization and the moral order. Boston: Routledge and Kegan Paul.

Jefferson, G. (1985) An exercise in the transcription and analysis of laughter. In T.A. van Dijk (ed.), Handbook of discourse analysis, vol. III: Discourse and dialogue. London: Academic Press, pp. 25-34.

Lash, S., B. Szerszynski, and B. Wynne (eds.) (1996) Risk, environment and modernity: Towards a new ecology. London.

Latour, B. (1981) Insiders \& outsiders in the sociology of science; or, how can we foster agnosticism? In Knowledge and society: Studies in the sociology of culture past and present, vol. 3. London: JAI Press Inc., pp. 199-216.

Latour, B. (1993) We have never been modern. Trans. C. Porter. New York: Harvester Wheatsheaf.

Latour, B. (1999) Pandora's hope: Essays on the reality of science studies. Cambridge, MA: Harvard University Press.

Latour, B. (2000) When things strike back: A possible contribution of 'science studies' to the social sciences. British Journal of Sociology 51.1: 107-123.

Latour, B. (2004a) Why has critique run out of steam? From matters of fact to matters of concern. Critical Inquiry 30: 225-247.

Latour, B. (2004b) Politics of nature: How to bring the sciences into democracy. Cambridge, MA: Harvard University Press. 
Mahajan, R. (2003) Full spectrum dominance: U.S. power in Iraq and beyond. New York: Seven Stories Press.

McKenzie, K.G. (1998) In the Gulf between prejudice and culture: Talking the experience of Westernexpatriates in the Middle East. Unpublished Ph.D. thesis, Loughborough University.

McKenzie, K. (2001) Fact and the narratives of war: Produced undecidability in accounts of armed conflict. Human Studies 24.3: 187-209.

McKenzie, K. (in submission) The institutional provision for silence: On the evasive nature of politicians' answers to reporters' questions. Journal of Language and Politics.

McKenzie, K., and T. van Teeffelen (1993) Taking the higher ground between West and Middle East: The discursive achievement of meta-perspective in representations of the Arab Other. Pragmatics 3.3: 305331.

Osborne, T., and N. Rose (1999) Do the social sciences create phenomena?: The example of public opinion research. British Journal of Sociology 50.3: 367-396.

Palast, G. (2003) The best democracy money can buy: The truth about corporate cons, globalization, and high-finance fraudsters. Revised American edition. New York: Penguin.

Parenti, M. (2003) Rulers of the planet: Why US leaders intervene everywhere. Global Dialogue 5.1-2: 91-104.

Pollner, M. (1987) Mundane reason: Reality in everyday and sociological discourse. Cambridge: Cambridge University Press.

Potter, J. (1996) Representing reality: Discourse, rhetoric and social construction. London: Sage.

Potter, J., and I. Litton (1985) Some problems underlying the theory of social representations. British Journal of Social Psychology 24: 81-90.

Sacks, H. (1992) Lectures on conversation, volumes I \& II, ed. G. Jefferson. Oxford: Blackwell.

Sacks, H., E.A. Schegloff, and G. Jefferson (1974) A simplest systematics for the organization of turntaking for conversation. Language 50.4: 696-735.

Schegloff, E.A. (1988) From interview to confrontation: Observations of the Bush/Rather encounter. Researchon Language and Social Interaction 22: 215-240.

Smith, D. (1978) K is mentally ill: The anatomy of a factual account. Sociology 12: 23-53.

Van Eemeren, F.H., and R. Grootendorst (1987) Fallacies in pragma-dialectical perspective. Argumentation 1: 283-301.

Van Eemeren, F.H., and R. Grootendorst (1992) Argumentation, communication, and fallacies: A pragma-dialectical perspective. Hillsdale, $\mathrm{NJ}$ : Erlbaum.

Walton, D. (1992) The place of emotion in argument. University Park, PA: Pennsylvania State UniversityPress.

Walton, D.N. (1996) Argumentation schemes for presumptive reasoning. Mahwah, NJ: Lawrence ErlbaumAssociates. 
Weltman, D. (2004) Political identity and the Third Way: Some social-psychological implications of the current anti-ideological turn. British Journal of Social Psychology 43: 83-98.

Winch, P. (1958) The idea of a social science and its relation to philosophy. Second edition. London: Routledge.

Wittgenstein, L. (1967) Zettle, ed. G.E.M. Anscombe and G.H. von Wright, trans. G.E.M. Anscombe. Oxford: Blackwell.

\section{Appendix: Transcription Conventions}

The transcription of talk that appears above is based on the well-known set of conventions initially developed by Gail Jefferson (1985; see also Sacks et al., 1974). Some of these conventions have been omitted in the extracts above where they are not significant to the analysis (e.g. pause timing between speaker turns at talk). Conventions which do appear in the transcript include the following:

full stop indicates completion intonation

comma indicates continuing intonation

underlining indicates additional stress

prolongation of sound indicated with colon(s)

false starts indicated with a dash followed by a single space

quotation as a presentational feature

arrows precede marked rise or fall in intonation

talk delivered with an increase in speed indicated with inward pointing guillemot

speaker overlap indicated with square brackets

unclear talk indicated with ' $\mathrm{x}$ ' for each syllable of speech you can simply take it there is a more racist.disagreement.

I happen to believe it was right, others believe it was wrong,

some people cannot understand it is possible

the conspiracy theorists out there u:m saying it's som:e terrible plot

I mean if you- he's going to have to fight for his election

the "green light" idea

I've got $\uparrow$ absolute $\downarrow$ ly no doubt

from the very beginning $>$ in respect of Iraq $<$ that some

Int that the [United] States

AmDip [Right.]

you know that sort of $\mathrm{xxxx-}$ 